\title{
THE EFFECTS OF ADRENERGIC DRUGS ON OVUM TRANSPORT THROUGH THE RABBIT OVIDUCT
}

\author{
J. P. POLIDORO,* G. R. HOWE AND D. L. BLAGK \\ Laboratory for Reproductive Physiology, Department of Veterinary and Animal Sciences, \\ University of Massachusetts, Amherst, Massachusetts, U.S.A.
}

(Received 30th October 1972)

\begin{abstract}
Summary. The effect of adrenergic drugs on ovum transport through the oviduct was studied at $24,36,48,60,72$ and $84 \mathrm{hr}$ post coitum (p.c.) in 240 mature, female Dutch-belted rabbits.

In untreated rabbits, ova were located in the area of the ampullaryisthmic junction at $24 \mathrm{hr}$ p.c.; most ova entered the uterus between 72 and $84 \mathrm{hr}$ p.c. Epinephrine increased $(P<0.01)$ the rate of ovum transport at 60 and $72 \mathrm{hr}$ p.c., and most of the ova were found in the uterus. Phenoxybenzamine $(\alpha$-blocker $)$ inhibited ovum transport at $48 \mathrm{hr}$ p.c. $(P<0.05)$, while propranolol $(\beta$-blocker) was ineffective in altering ovum transport in any of the time periods.

Regulation of ovum transport through the rabbit oviduct appeared to be governed in part, by a neural-endocrine interrelationship; this relationship could be altered by adrenergic stimulants and blocking agents.
\end{abstract}

\section{INTRODUGTION}

Sympathetic innervation to the smooth musculature of the female genital tract is extensive; the physiological and pharmacological significance of this innervation has been extensively reviewed (Brundin, 1965, 1969; Pauerstein, Woodruff \& Zachary, 1968; Marshall, 1970).

By histochemical (Falck, 1962) and biochemical (Haggendal, 1963) methods for norepinephrine, the degree of adrenergic innervation has been shown to increase from the ovarian to the uterine end of the rabbit oviduct (Brundin, 1964c, 1965; Brundin \& Wirsen, 1964; Owman, Rosengren \& Sjoberg, 1966). In the rabbit, the rich adrenergic innervation has been correlated to a sphincterlike activity (Brundin, 1964a, b, 1965).

Longley, Black \& Currie (1968a, b) have shown that autonomic drugs can alter ovum transport at $36 \mathrm{hr}$ post coitum (p.c.) and that the effect can be potentiated by oestrogen or progesterone. Phenoxybenzamine inhibits ovum transport; this effect can be potentiated by oestrogen. Epinephrine and propranolol are ineffective at $36 \mathrm{hr}$ p.c. unless accompanied by exogenous oestrogen. Longley et al. (1968b) concluded that the rabbit oviduct possesses $\alpha$ - and

* Present address: Ortho Research Foundation, Raritan, New Jersey, U.S.A. 
$\beta$-adrenoceptors and that the $\alpha$-receptors are most influential in ovum transport.

The present study evaluates the effect of adrenergic drugs on ovum transport from 24 to $84 \mathrm{hr}$ p.c.

\section{MATERIALS AND METHODS}

A total of 240 mature, female Dutch-belted rabbits, obtained from our colony or a local rabbitry, were used in this investigation. The rabbits were allocated to four groups of sixty does each, which were individually isolated for 1 week or more and were allowed free access to food and water.

The effects of epinephrine and its antagonists, phenoxybenzamine (an $\alpha$ adrenoceptor blocker) and propranolol (a $\beta$-adrenoceptor blocker) on ovum transport were studied separately in three experimental groups. The fourth group served as a control.

All drugs were injected subcutaneously in aqueous solution or suspension. Epinephrine was purchased in solution; phenoxybenzamine and propranolol were prepared daily in sterile physiological saline $(0.9 \%)$. The drugs were administered as follows: epinephrine $-500 \mu \mathrm{g} / \mathrm{kg}$ body weight, repeated at 6-hr intervals; phenoxybenzamine- $3 \mathrm{mg} / \mathrm{kg}$ body weight, repeated at 4-hr intervals; propranolol--7 mg/kg body weight, repeated at 3-hr intervals.

The doses selected were previously used in this laboratory and were known to keep the animal under the influence of the drug between injections (Longley et al., 1968a, b).

Animals in each group were mated to one or two fertile males. Following mating and an intravenous injection of $2.5 \mathrm{mg} \mathrm{LH}$ (Kennelly \& Foote, 1965), ten animals from each group were killed at either 24,36, 48,60, 72 or $84 \mathrm{hr}$ p.c., after having received one of the drugs for a 12-hr period preceding death. The rabbits were killed with an overdose of sodium pentobarbital, the abdomen was opened and the reproductive tract was immediately frozen with isopentane cooled to the temperature of liquid nitrogen (Longley \& Black, 1968). After thawing, the oviducts and uteri were removed and trimmed of their supporting mesentery. They were then fixed and cleared according to the method of Orsini (1962). The oviducts were stored individually in tubes of benzyl benzoate. The cleared reproductive tracts were placed in a glass boat with a millimeter scale etched on the bottom and examined with a dissecting microscope to determine the exact position of each ovum, which was then expressed as a percentage of the total oviduct length (infundibulum to uterotubal junction). Ova recovered from the uterus were considered to be $100 \%$ transported.

The number of CL on each ovary was recorded. The percentage recovery of ova was determined for each group by comparing the number of CL with the number of ova observed in the cleared oviducts and uteri.

A fourth group of sixty untreated rabbits served as controls and they were examined in the same manner as the experimental animals.

Statistical comparisons between treatments were determined by analysis of variance for a split-plot design. A program for this analysis (BMDO8V) was obtained from a Biomedical Computer Programs Manual (BMD), the 
data tabulated, punched on IBM cards and subsequently run on a CDC 3600 computer (University of Massachusetts Computer Center). Following the analysis of variance, the F test and Duncan's New Multiple Range Test were utilized to test and locate significance (Steel \& Torrie, 1960).

\section{RESULTS}

The ovum recovery rate for the total experiment was $96 \%$. The rate of ovum transport in the control groups is presented in Table 1 . By $24 \mathrm{hr}$ p.c., the ova had traversed over $50 \%$ of the total oviduct length and were situated in the vicinity of the ampullary-isthmic junction. Ovum transport through the

Table 1. Distance of ovum transport in cleared oviducts and uteri of rabbits

\begin{tabular}{|c|c|c|c|c|c|c|}
\hline \multirow[b]{2}{*}{ Treatment } & \multicolumn{6}{|c|}{ Hours p.c. } \\
\hline & 24 & 36 & 48 & 60 & 72 & 84 \\
\hline Control & $\begin{array}{l}54 \cdot 1 \\
(1 \cdot 53)\end{array}$ & $\begin{array}{l}62 \cdot 0 \\
(1 \cdot 44)\end{array}$ & $\begin{array}{l}69 \cdot 0 \\
(1.40)\end{array}$ & $\begin{array}{l}71 \cdot 3 \\
(1 \cdot 14)\end{array}$ & $\begin{array}{l}79 \cdot 3 \\
(1 \cdot 17)\end{array}$ & $\begin{array}{l}95.5 \\
(2 \cdot 63)\end{array}$ \\
\hline Epinephrine & $\begin{array}{l}51 \cdot 6 \\
(2.53)\end{array}$ & $\begin{array}{l}61.9 \\
(2.50)\end{array}$ & $\begin{array}{l}71.3 \\
(1.99)\end{array}$ & $\begin{array}{l}82 \cdot 3 \\
(3 \cdot 10)\end{array}$ & $\begin{array}{l}95.4 \\
(1.90)\end{array}$ & $\begin{array}{l}98.9 \\
(1 \cdot 10)\end{array}$ \\
\hline Phenoxybenzamine & $\begin{array}{l}48.9 \\
(1 \cdot 63)\end{array}$ & $\begin{array}{l}60 \cdot 5 \\
(1.58)\end{array}$ & $\begin{array}{l}62.9 \\
(2 \cdot 20)\end{array}$ & $\begin{array}{l}68 \cdot 8 \\
(1.50)\end{array}$ & $\begin{array}{l}77 \cdot 4 \\
(2 \cdot 00)\end{array}$ & $\begin{array}{l}96.8 \\
(1.63)\end{array}$ \\
\hline Propranolol & $\begin{array}{l}50 \cdot 6 \\
(2 \cdot 37)\end{array}$ & $\begin{array}{l}60 \cdot 0 \\
(1.73)\end{array}$ & $\begin{array}{l}65.4 \\
(1.40)\end{array}$ & $\begin{array}{l}74.9 \\
(3.90)\end{array}$ & $\begin{array}{l}76 \cdot 8 \\
(1 \cdot 16)\end{array}$ & $\begin{array}{l}95.1 \\
(1.90)\end{array}$ \\
\hline
\end{tabular}

Values expressed as mean $\%$ distance transported with S.E. in parentheses.

Table 2. Distance of transport for rabbit ova remaining in oviducts at $24,36,48$, 60,72 and $84 \mathrm{hr}$ p.c.

\begin{tabular}{|c|c|c|c|c|c|c|}
\hline \multirow[b]{2}{*}{ Treatment } & \multicolumn{6}{|c|}{ Hours p.c. } \\
\hline & 24 & 36 & 48 & 60 & 72 & 84 \\
\hline $\begin{array}{l}\text { Control } \\
\text { Epinephrine } \\
\text { Phenoxybenzamine } \\
\text { Propranolol }\end{array}$ & $\begin{array}{l}54 \cdot 1 \\
51 \cdot 6 \\
48 \cdot 9 \\
50 \cdot 6\end{array}$ & $\begin{array}{l}62 \cdot 0 \\
61 \cdot 9 \\
60 \cdot 5 \\
60 \cdot 0\end{array}$ & $\begin{array}{l}69 \cdot 0 \\
71 \cdot 3 \\
62 \cdot 9 \\
64 \cdot 7\end{array}$ & $\begin{array}{l}71 \cdot 3 \\
76 \cdot 0(8)^{*} \\
68 \cdot 8 \\
72 \cdot 5\end{array}$ & $\begin{array}{l}78 \cdot 4 \\
81 \cdot 1(5) \\
76 \cdot 8 \\
76 \cdot 8\end{array}$ & $\begin{array}{l}77 \cdot 0(3) \\
81 \cdot 5(1) \\
82 \cdot 2(5) \\
81 \cdot 2(5)\end{array}$ \\
\hline
\end{tabular}

Values expressed as mean $\%$ distance transported.

* Group values representing fewer than ten animals with some ova remaining in oviducts.

isthmus was much slower, requiring about $2 \frac{1}{2}$ days. At 48 and $60 \mathrm{hr}$ p.c., ova were located in about the same position. The majority of ova reach the uterus by $84 \mathrm{hr}$ p.c. In one animal, however, some ova had reached the uterus by $72 \mathrm{hr}$ p.c. As shown in Table 2, the position of control ova which had not entered the uterus by $84 \mathrm{hr}$ p.c. was similar to that found at $72 \mathrm{hr}$.

Epinephrine did not significantly alter ovum transport at 24,36 or $48 \mathrm{hr}$ p.c. Epinephrine increased $(P<0.01)$ the rate of transport at 60 and $72 \mathrm{hr}$ p.c. when most ova were found in the uterus. The position of those remaining in the oviduct was similar to that found in controls (Table 2).

Phenoxybenzamine inhibited ovum transport at 48 hr p.c. $(P<0.05)$, but did not alter ovum transport at 24,36,60, 72 or 84 hr p.c. Ovum transport 
was similar in the phenoxybenzamine-treated groups at 36,48 and $60 \mathrm{hr}$ p.c. The positions of ova at other time periods were significantly different.

Propranolol did not alter ovum transport during any of the time periods investigated. Ovum transport in propranolol-treated animals at 60 and $72 \mathrm{hr}$ p.c. was similar, while all other within-treatment comparisons differed with time. Although propranolol did not significantly alter the mean transport rate when compared to controls, some ova were transported to the uterus as early as 48 and $60 \mathrm{hr}$ p.c.

Table 3. Results of Duncan's New Multiple Range Test on the four treatment means for rabbits killed at 24, 36, $48,60,72$ and $84 \mathrm{hr}$ p.c.

\begin{tabular}{|c|c|c|c|c|}
\hline Hours after coitus & \multicolumn{4}{|c|}{ Treatment means } \\
\hline 24 & $\begin{array}{c}(\mathrm{Ph})^{*} \\
48 \cdot 9\end{array}$ & $\begin{array}{l}(\mathrm{Pr}) \\
50.6\end{array}$ & $\begin{array}{c}(E) \\
51 \cdot 6\end{array}$ & $\begin{array}{c}(\mathrm{C}) \\
54 \cdot 1\end{array}$ \\
\hline 36 & $\begin{array}{l}(\mathbf{P r}) \\
60 \cdot 0\end{array}$ & $\begin{array}{l}(\mathbf{P h}) \\
60.5\end{array}$ & $\begin{array}{c}(\mathrm{C}) \\
61 \cdot 9\end{array}$ & $\begin{array}{c}(E) \\
62 \cdot 0\end{array}$ \\
\hline 48 & $\begin{array}{l}(\mathrm{Ph}) \\
62 \cdot 9\end{array}$ & $\begin{array}{l}(\mathrm{Pr}) \\
65.4\end{array}$ & $\begin{array}{c}(\mathrm{C}) \\
69 \cdot 0\end{array}$ & $\begin{array}{c}(\mathbf{E}) \\
71 \cdot 3\end{array}$ \\
\hline 60 & $\begin{array}{l}(\mathrm{Ph}) \\
68 \cdot 8\end{array}$ & $\begin{array}{l}\text { (C) } \\
71 \cdot 3\end{array}$ & $\begin{array}{l}(\mathrm{Pr}) \\
74.9\end{array}$ & $\begin{array}{c}(E) \\
82 \cdot 3\end{array}$ \\
\hline 72 & $\begin{array}{l}(\mathbf{P r}) \\
76 \cdot 8\end{array}$ & $\begin{array}{l}(\mathrm{Ph}) \\
77 \cdot 4\end{array}$ & $\begin{array}{l}(\mathrm{C}) \\
79 \cdot 3\end{array}$ & $\begin{array}{c}(\mathrm{E}) \\
95.4\end{array}$ \\
\hline 84 & $\begin{array}{l}(\mathrm{Pr}) \\
95 \cdot 1\end{array}$ & $\begin{array}{c}(\mathrm{C}) \\
95.5\end{array}$ & $\begin{array}{l}(\mathrm{Ph}) \\
96.8\end{array}$ & $\begin{array}{c}(E) \\
98.9\end{array}$ \\
\hline
\end{tabular}

All means underscored by the same line are not significantly different from one another.

$*(\mathrm{Ph})=$ phenoxybenzamine $;(\mathrm{Pr})=$ propranolol $;(\mathrm{E})=$ epinephrine; $(\mathbf{C})=$ control.

Table 4. Number of corpora lutea and oviduct length for the right and left ovaries and oviducts of rabbits in each of the treatments

\begin{tabular}{|c|c|c|c|c|}
\hline \multirow{2}{*}{ Treatment } & \multicolumn{2}{|c|}{$\begin{array}{l}\text { Mean number of } \\
\text { corpora lutea }\end{array}$} & \multicolumn{2}{|c|}{$\begin{array}{c}\text { Mean oviduct } \\
\text { length }(\mathrm{cm})\end{array}$} \\
\hline & Right & Left & Right & Left \\
\hline $\begin{array}{l}\text { Control } \\
\text { Epinephrine } \\
\text { Phenoxybenzamine } \\
\text { Propranolol }\end{array}$ & $\begin{array}{l}4 \cdot 25 \\
4 \cdot 57 * \\
4 \cdot 73 \\
5 \cdot 00^{*}\end{array}$ & $\begin{array}{l}4 \cdot 07 \\
3 \cdot 90 \\
4 \cdot 40 \\
4 \cdot 32\end{array}$ & $\begin{array}{l}12 \cdot 93^{* *} \\
11 \cdot 27 * * \\
12 \cdot 15^{* *} \\
12 \cdot 29 * *\end{array}$ & $\begin{array}{l}11.91 \\
10.29 \\
11.26 \\
11.45\end{array}$ \\
\hline Overall mean & $4 \cdot 64 * *$ & $4 \cdot 17$ & $12 \cdot 16^{* *}$ & $11 \cdot 23$ \\
\hline
\end{tabular}


Statistical comparisons of all four treatment means within each time period are shown in Table 3.

An analysis of variance incorporating all treatments and time periods was used to compare ovum transport in the left oviduct with that in the right. Ovum transport on the left side was faster $(P<0.01)$ than on the right; this difference was apparent in most time periods for all four treatments.

The mean number of ovulations per rabbit was $8 \cdot 8$ (Table 4 ). The number of CL on the right ovary significantly $(P<0.05)$ exceeded that on the left in the epinephrine- and propranolol-treated groups. There was no significant difference between the mean number of CL on the right and left ovaries in the control and phenoxybenzamine-treated groups. When all treatment means were combined, the numbers of CL for the right and left sides were 4.64 and $4 \cdot 17$, respectively. This difference was highly significant $(P<0 \cdot 01)$.

As can be seen from Table 4, the mean length of the right oviduct $(12.2 \mathrm{~cm})$ was significantly $(P<0.01)$ greater than that of the left $(11.2 \mathrm{~cm})$.

\section{DISCUSSION}

The mean rate of ovum transport in the left oviduct exceeded that of the right in most of the time periods tested within the four treatments $(P<0 \cdot 01)$. This is in agreement with the data of Longley et al. (1968b), who reported similar findings utilizing the same clearing technique. The fact that the mean length of the right oviduct was $1.0 \mathrm{~cm}$ longer than the left might account for the difference.

It is apparent that the normal rate of ovum transport in the ampulla differs from that of the isthmus. This is in agreement with the findings of earlier studies (Harper, 1961) that the rate of movement is not uniform over the entire length of the oviduct. Ova traverse over $50 \%$ of the oviduct length by $24 \mathrm{hr}$ p.c. (see Blandau, 1969 for complete reference).

It is generally believed that rabbit ova are retained in the vicinity of the ampullary-isthmic junction until about $48 \mathrm{hr}$ p.c. and then enter the isthmus (Greenwald, 1959, 1961). Recently, the clearing method has been used and found to be a more accurate method for determination of ovum position (Longley \& Black, 1968; Howe, 1970). In the present study, most ova had entered the ovarian end of the isthmus by $36 \mathrm{hr}$ p.c.

Transport through the isthmus is extremely slow and appears to be dependent upon muscle contraction (Black \& Asdell, 1958). Ovum transport was relatively linear until 48 to $60 \mathrm{hr}$ p.c. when the ova were similarly located at $70 \%$ of the tubal length.

Transport through the uterotubal junction is rapid; only one ovum was found in this area. This is in agreement with the findings of Howe (1970) who, also, did not recover ova in this area. Although some ova were found in the uterus at $72 \mathrm{hr}$ p.c., most of them entered between 72 and $84 \mathrm{hr}$ p.c. Since the location of the few ova remaining in the oviduct at $84 \mathrm{hr}$ was similar to the position of ova at $72 \mathrm{hr}$ p.c., the majority of ova must traverse the last $20 \%$ of the tube rapidly. It appears, therefore, that the normal rate of ovum transport is regulated by the isthmus and uterotubal junction. 
Adrenergic control of the rate of movement of ova through the oviduct is closely related to the morphology of the tube. Ovum transport is rapid in the ampulla where the innervation is least (Brundin \& Wirsen, 1964; Brundin, 1965; Owman et al., 1966).

Increased musculature and innervation of the isthmus is undoubtedly involved in slower transport of ova through this segment (Brundin, 1965). The results of our study agree with those of Longley et al. (1968b), Pauerstein, Fremming \& Martin (1970) and Bodkhe \& Harper (1971) who concluded that functional adrenergic innervation is modified by the endocrine state of the animal. Changes in the concentration of circulating steroid hormone following ovulation might explain the variable response to adrenergic drugs on ovum transport observed in this study. Since epinephrine retards ovum transport only when administered with oestrogen (Longley et al., 1968b) and oestrogen-induced arrest of ova at the ampullary-isthmic junction can be antagonized with phenoxybenzamine (Pauerstein et al., 1970), it appears that oestrogen increases the activity of $\alpha$-adrenoreceptors preventing the ova from entering the isthmus. Norepinephrine, in the oviduct, is lower when ova are in the upper isthmus of the rabbit (Bodkhe \& Harper, 1971). Oestrogen production is also reduced during gamete transport (Eaton \& Hilliard, 1971).

The most noticeable neuroendocrine effect in the present study was the epinephrine-induced increase in ovum transport at 60 and $72 \mathrm{hr}$ p.c. Epinephrine was ineffective at earlier time periods. Eaton \& Hilliard (1971) reported that ovum transport occurs during an acute withdrawal of ovarian steroids, and that both oestrogen and progestin levels begin to rise toward the end of transport and before implantation. Since the response of the oviduct to catecholamines appears to be enhanced by oestrogens (Longley et al., 1968b), the suspected increase in oestrogen and progestins toward the end of transport may account for the epinephrine effects at 60 and $72 \mathrm{hr}$ p.c.

In the present study, phenoxybenzamine inhibited ovum transport at $48 \mathrm{hr}$ p.c. Longley et al. (1968b) noted the same effect at $36 \mathrm{hr}$.

Although the stimulatory effect of the catecholamine is generally attributed to their $\alpha$-activity (Brundin, 1965; Longley et al., 1968b), it is not known why phenoxybenzamine $(\alpha$-blocker) was ineffective in lowering the rate of ovum transport substantially below the controls of 60 and $72 \mathrm{hr}$ p.c. The failure of propranolol to alter transport significantly does not necessarily mean that the $\beta$-activity noted in the rabbit oviduct by Martin, Ware, Crosby \& Pauerstein (1970) may not contribute to the regulation of gamete transport.

\section{AGKNOWLEDGMENTS}

The work reported here was submitted in part by the senior author to the Graduate School, University of Massachusetts, in partial fulfilment of the requirements for the Ph.D. degree, and was supported by the National Institute of Health Contract Grant No. 69-2132 entitled 'Neural Control of the Mammalian Oviduct'.

\section{REFERENCES}

Black, D. L. \& Aspell, S. A. (1958) Transport through the rabbit oviduct. Am. F. Physiol. 192, 63. 
BLANdAu, R. J. (1969) Gamete transport-comparative aspects. In: The Mammalian Oviduct. Eds. E. S. E. Hafez and R. J. Blandau. University of Chicago Press, Chicago.

Bodkhe, R. R. \& HARPER, M. J. K. (1971) Mechanism of egg transport: changes in amount of adrenergic transmitter in the genital tract of normal and hormone treated rabbits. In: The Regulation of Mammalian Reproduction. Ed. S. J. S. Segal. Thomas, Springfield, Illinois.

Brundin, J. (1964a) A functional block in the isthmus of the rabbit Fallopian tube. Acta physiol. scand. $60,295$.

Brundin, J. (1964b) An occlusive mechanism in the Fallopian tube of the rabbit. Acta physiol. scand. 61, 219.

Brundin, J. (1964c) The distribution of noradrenaline and adrenaline in the Fallopian tube of the rabbit. Acta physiol. scand. 62, 156.

Brundin, J. (1965) Distribution and function of adrenergic nerves in the rabbit Fallopian tube. Acta physiol. scand. 66, Suppl. 259.

Brundin, J. (1969) Pharmacology of the oviduct. In: The Mammalian Oviduct. Eds. E. S. E. Hafez and R. J. Blandau. University of Chicago Press, Chicago.

Brundin, J. \& WiRSEN, G. (1964) The distribution of adrenergic nerve terminals in the rabbit oviduct. Acta physiol. scand. 61, 203.

Eaton, L. W. \& Hilliard, J. (1971) Estradiol-17 $\beta$ and progestin released by the rabbit ovary from mating through implantation. Biol. Reprod. 5, 89 (Abstr.).

FalcK, B. (1962) Observations on the possibilities of the cellular localization of monamines by a fluorescence method. Acta physiol. scand. 56, Suppl. 197.

Greenwald, G. S. (1959) Tubal transport of ova in the rabbit. Anat. Rec. 133, 386.

Greenwald, G. S. (1961) A study of the transport of ova through the rabbit oviduct. Fert. Steril. 12, 80.

Haggendal, J. (1963) An improved method for fluorimetric determination of small amounts of adrenaline and noradrenaline in plasma and tissues. Acta physiol. scand. 59, 242.

HARPER, M. J. K. (1961) The mechanisms involved in the movement of newly ovulated eggs through the ampulla of the rabbit Fallopian tube. F. Reprod. Fert. 2, 522.

Howe, G. R. (1970) A study of egg transport in the rabbit using a freezing-clearing technique. $\mathcal{F}$. Reprod. Fert. 21, 339.

Kennelly, J. J. \& Foote, R. H. (1965) Superovulatory response of pre- and post-pubertal rabbits to commercially available gonadotrophins. F. Reprod. Fert. 9, 177.

Longley, W. J. \& BlaCK, D. L. (1968) Comparisons of methods for locating ova in the oviduct of the rabbit. F. Reprod. Fert. 16, 69.

Longley, W. J., Black, D. L. \& GuRrie, G. N. (1968a) Oviduct circular muscle response to drugs related to the autonomic nervous system. $\mathcal{J}$. Reprod. Fert. 17, 95.

Longley, W. J., Black, D. L. \& Currie, G. N. (1968b) Ovarian hormone control of ovum transport in the rabbit as influenced by autonomic drugs. F. Reprod. Fert. 17, 579.

Marshall, J. M. (1970) Adrenergic innervation of the female reproductive tract: anatomy, physiology and pharmacology. Ergebn. Physiol. 62, 6.

Martin, J. E., Ware, R. J., Grosby, R. J. \& Pauerstein, S. J. (1970) Demonstration of beta adrenergic receptors in the rabbit oviduct. Gynecol. Invest. 1, 82.

Orsini, M. W. (1962) Technique of preparation, study and photography of benzyl-benzoate cleared material for embryological studies. F. Reprod. Fert. 3, 283.

Owman, G., Rosengren, E. \& SJoberg, N. O. (1966) Origin of the adrenergic innervation to the female genital tract of the rabbit. Life Sciences, 5, 1389.

Pauerstein, G. J., Fremming, B. D. \& Martin, J. E. (1970) Estrogen-induced tubal arrest of ovum: antagonism by alpha adrenergic blockage. Obstet. Gynec, $\mathcal{N} . Y .35,671$.

Pauerstein, C. J., Woodruff, J. D. \& Zachary, A. S. (1968) Factors influencing physiologic activities in the Fallopian tube; the anatomy, physiology and pharmacology of tubal transport. Obstetl gynec. Surv. 23, 215.

Steel, R. \& Torrie, J. (1960) Principles and procedures of statistics. McGraw-Hill, New York. 